\title{
AN IMPROVED METHOD FOR MEASURING RED BLOOD CELL FILTERABILITY
}

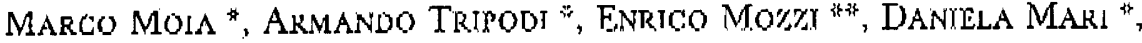 \\ Pier Mannuccio Mannucci"
}

Unioersilè degli Studi di Milano

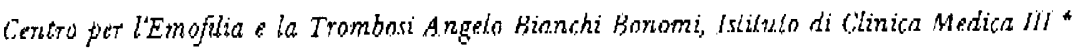

Istimuto di Clinieu Chirurgica $\mathrm{II}^{* *}$

The blood flow rate is, according to the Poiseuille law, a function of vessel size and huid viscosity ${ }^{3}$. Viscosity is determined by a liction between adjacent layers of the fluid and, with vasoconstriction, it determines resistance to flow. Some fluids like water or plasma are called 'Newtonian' because they havc a constant viscosity dependent only on tcruperature. Blood viscosily, on the contrary, is a function of the shear rate and is considered a 'non-Ncwtonian' parameler. For instance, this means that blood in veins (where shear rates arc low) is more viscid than in arteries (where shear rates arc highi)

The viscosity of whole blood mainly depends on the number and properties of red blood cells (RBC), i.e. the packed cell volume (PCV) and red ccll deform. ability $(\mathrm{RCD})^{2}$. Under normal conditions, leukocytes and platclets have: litrle or no influence on blood viscosity. of the plasma proteins, only tibrinogen is importarit, since at low shear rates it is able to produce RBC aggregation ('rouleaux'), 1u,1s. Annong the numerous available methods for measurixg $\mathrm{RCD}^{2,4,1,12,14}$, the most widely used arc those which measure the red cell filterability ( $R C F$ ) through micropore mombrancs.

There are several micthods for measuring RCF using whole blood or red blood cells suspended in salinc solution or filtered plasma. All these methods arc based on the same principle, differing only in the final stage. The end points can be either the quantity of RBC filtered within a fixed tine under variable or constant hydrostatic pressure ${ }^{7.13}$ or the pressure increase under constant blood llow?

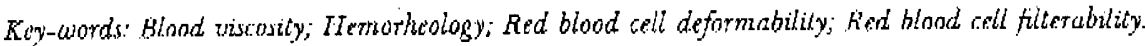

Accepted for publication on May 13, 1985.

La Ricerca Clin. Lab. 15, $12 \%, 1985$. 
Since these methods are not woll reproducible, employing a variation coefficient of $15.20 \%$ wo have developed a now simple method able to measurc RCF by weighing the amount of RBC filtered through micropore mintrabranes (red cell filterability by weighing: RCFW). The results obtained with this method have becn compared with those obcained using a widely cmployed method (Dormandy techuique)?

\section{MATERLALS AND METHODS}

\section{Materials}

Phosphate-buffered saline (PBS): $39 \mathrm{~g} \mathrm{Na}_{2} \mathrm{IPO}_{4}-12 \mathrm{H}_{2} \mathrm{O}$ and $5 \mathrm{~g} \mathrm{~K}_{2} \mathrm{HPO}_{4}$ are made up to 11 with distilled water (pH 7.4 , osmolality $800 \mathrm{mOsm} / \mathrm{kg}$ );

EDTA: $6 \mathrm{~g}$ of EDTA are dissolved in $10 \mathrm{~mol}$ of distilled water; $10 \mu \mathrm{l}$ of this solution are used in order to prevent coagulation of $5 \mathrm{ml}$ of blood;

glutaraldehyde: $0.5 \%$ in distilled water;

polycarbonate membranes (Nuclepore, batch no. 54FOCS4.) $13 \mathrm{~mm}$ in diamcter with $5-\mu$ pores.

\section{Methods}

$R C F W \cdot 5 \mathrm{ml}$ of blood are drawn with minimal venous stasis and anticoagulated with EDTA. Blood is irruxuediately centrifuged at $100 \mathrm{~g}$ for $3 \mathrm{~min}$ and then at $1,000 \mathrm{~g}$ for $7 \mathrm{~min}$ in order to obtain a better separation of red blood cells from the buffy-coat. Plasmia and buffy coat are aspirated and discardcd. "The packed RBC are then brought to the original volume: with PBS. This procedure is repeated three tirncs. More than $95 \%$ of leukocytes and platclets are elinni. rated by three washings. A suspension of $5 \%$ RBC in PBS is then preparcd and $2 \mathrm{ml}$ of this suspension are filtered for $30 \mathrm{sec}$, under gravity, through the microporc membranes and, finally, the filtrate is weighed.

In order to eliminate the effects of membrane variability, $2 \mathrm{ml}$ of PBS arc: filtcred through the same membrane for 30 sec before the RBC suspcnsion, and then wcighed.

The filterability index (FT) is calculated as follows:

$$
\text { FI }=\frac{\text { weight of RBC filtrate }}{\text { weight of PBS liltrate }}
$$

The procedure is carried out in triplicate.

Dormandy technique - Blood samples are anticoagulated with heparin and centrifuged at $1,000 \mathrm{~g}$ for $15 \mathrm{~min}$; the plasirla fraction is filtcred in order to climinate leukocytcs and platclets. The buffy coat is discurded and the RBC are resuspended in their own plasma at. a $5 \%$ concentration. The FI is calculated by photometrically measuring the hemoglobin concentration of the RBC fil. tered during $1 \mathrm{~min}$. The procedure is carried out in triplicate.

\section{RESULTS}

Reproducibility. The within-assay reproducibility was cxpressed as CV\% and assessed lor the two techniques from 10 replicates from a single blood donor. 
M. MoIA et al.

\begin{tabular}{|c|c|c|c|c|c|}
\hline \multirow{2}{*}{ method } & \multirow{2}{*}{$\begin{array}{l}\text { normal rartge } \\
\text { (mean } \pm 25 D)\end{array}$} & \multicolumn{4}{|c|}{ within assny precision } \\
\hline & & no. & mean & SD & CV\% \\
\hline RCFW & 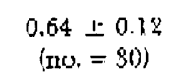 & 10 & 0.68 & 0.01 & 5.3 \\
\hline Dormandy rechnique & $\begin{array}{c}0.80 \pm 0.18 \\
(n 0-20)\end{array}$ & 10 & 0.66 & 0.05 & 7.2 \\
\hline
\end{tabular}

Tab. 1 - Comparison of the resultis obtuined with the two methods.

Table 1 shows the results: CV\% were 5.3 and 7.2 for RCFW and Dormandy technique, respectively.

Nornal range - Normal tarnges were established from 20 satmples from normal subjects with Dormandy technique and from 80 samples from normal subjects with the RCFW. The FI value was $0.68-10.12$ (mean $\pm 2 \mathrm{SD}$ ) and $0.80 \pm 0.18$ with RCFW and Dormandy tectmique, respectively.

Sersititity to hardened $R B C$ - A $5 \%$ RBC suspension in PBS was rigidified with $0.5 \%$ glutaraldehyde at rom temperature for $2 \mathrm{~h}$ by continuous stirring. Incrcasing amounts of this suspension were added to samples from a single donor, in order to obtain hardened RBC concentrations ranging frotn 0.0001 to $0.08 \%$. The susperisions were then processed by the two techriques. For a dircct comparison of the two techniqucs, fl values obtained with increasing hardened RBC concentrations were expressed as percentages of the values obtained with both techniques when no hardened RBC have been added. With both techniques, $\mathrm{Fl}$ values decrease with increasing concentrations of harden" ed RBC. However, with RCFW results significantly differed from normal RRC. suspensiors using concentrations as small as $0.0005 \%$, while with Dormandy technique they significantly differed only at a concentration of $0.005 \%$. In addition, the FI values obtained by RCFW were lower than those obtained by Dormandy technique at concentrations of hardened RBC up to $0.01 \%$ (fig. 1 ).

\section{DISCUSSION}

Little is still known about the relationship between RCD, RCF, blood viscosity and blood flow, hut the results of some hemorheological investigaLions ${ }^{2, y, 13}$ suggest that filtration represents a good parameter for measuring $\mathrm{RCD}$ in vivo.

Since reproducibility is one of the major prerequisites for every clinically used technique, we have tried to improve it by modifying the end-point of currently used fllration techuiques through micropore membrancs essentially by weighing the amount of filtered RBC, related to the quantity of PBS filtcred during the same interval of time, in order to compensate for small differences in the number and size of micropores of the different filters.

The mechod has proved to be reliable, with a reproducibility better than that of the widely used Dormandy technique. Moreover, its sensitivity to artificially harderied $\mathrm{RBC}$ seems to be greater and it is able to differentiatc: 


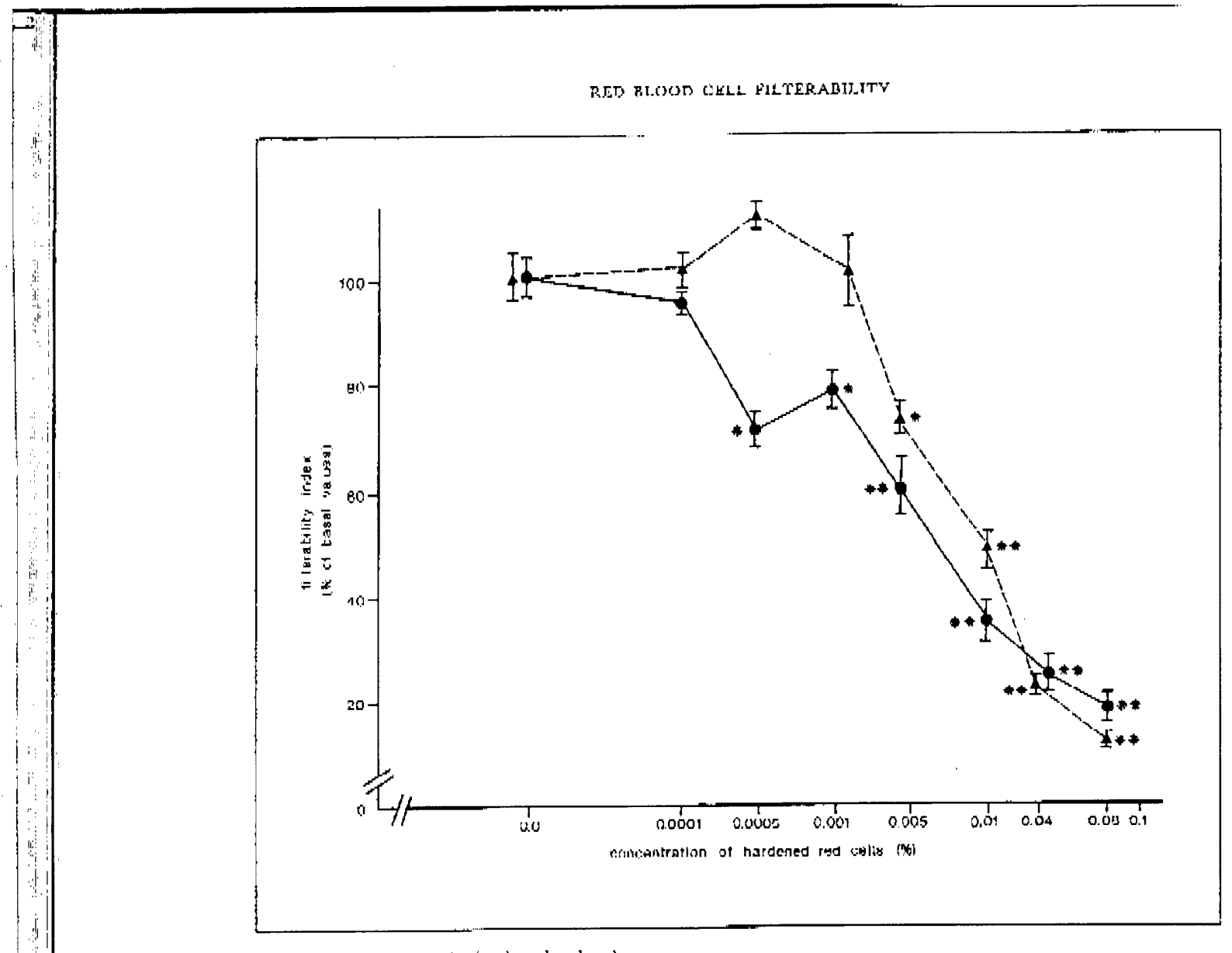

"p $0.005 ; \%$ p $<0,001$ (ms. basal values).

Fix, 1 . Filterability index yalues obtained using the KCFW method (-) and the Dormandy

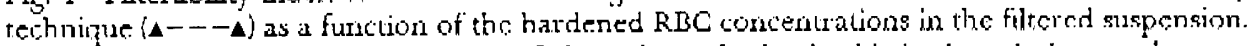
Resuls are expressed as percentages of the valucs obtained with both techniques wheri no hardened RBC have becn added.

samples containing as little as $0.0005 \%$ hardened $\mathrm{RBC}$, while the Dormandy technique does not differentiate them until a $0.005 \%$ concentration.

Since the filtration steps are simila for both tcchniques, the most likely explanation for the differences in performance is that variability in the photometric measurement of hemoglobin content is greater than that of direct weighing, making our modification of the technique more reproducible.

\section{SUMMARY}

A new simple method for measuring red blood cell (RBC) filcability by woighing the anuunt of RBC filtercd through mictopore mombranes is described. Red cell filterabitity by weighing (RCFW) is delermined on washed RBC resuspended in phosphate-buffered saline (PBS) at low $(5 \%$ thematocrit. The filtration step is pertormed using gravity alone and the amowne of the filtered suspension is refered to be filtration of pBS alome though dhe same membrane. 'The new method shows a reproducibility better than that of the wiriely used Dorzididy techninue, with a lower coefficiont of variztion $(5.3$ wis $7.2 \%)$ and a higher sensitiviry to artititially hardonce $\mathrm{RHC}$. 
M. Mris et لd.

\section{REFERLNCES}

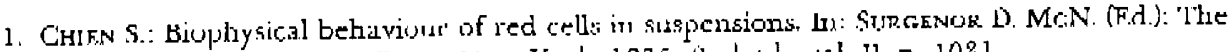
red blood cell. Acaderriic Press, New York, 1975 ; and ed, vol. 1], p. 1031.

2. Cmen S.: Principles atd techniques for asscssing erythocyte deformability - Blood Cclls 3 , $71,1977$.

3. Cunn S: Determinants of blood viscosity and red cell deformahility - Scand. J. clin. Lab. Invest. 41 (Suppl. 156), 7, 1981.

1. Dintenrass l..: Blood microrheology. Viscosily factors in blood fow, ischaemia and throur. bosis. Butcerworthis, London, 1971.

5. DinTENensg L., Fordes C. D.: Viscosity of blond in patients with myocardial infarction, haerrophilin and thyroid diseases. Efferts of fibringgen, albumin and globulin. Biorkeology 10), 475, 1973

6. DI P'ERRI T.: Rheological tactors in circulatory disoidcrs - Angrology 30, 480, 1979.

7. Donos A. J., O'Reilly M. J. G.. Yates G. J. P., Cotton L. T., Flute P. T., Dormandy J. A.: Hacmorheological remponsc to plisstuid exchange in Raynaud's synudrome Brit. med.]. if, $1186,1979$.

8. Foroons $s$.: Ruolo della viscosita cmatica nella ischemia degli arti. In: Di PerRi T., FischetTI

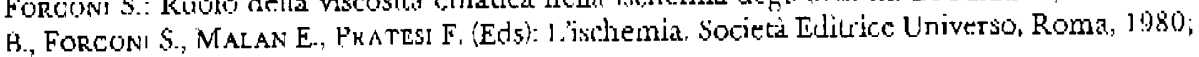
p. 227.

9. LEDLOND F. H., COULOMPP. L.: The measurements of erythrocyte deformability using microponre rembranes. A serisicive technique with clinical applications - J. Lab. din. Med. 94, 193, 1979.

10. Merul F. W. Cokpi.f. G. C., BritTen A., WhLL.S K. E. Ji.: Nom-Newtonian rheolugy of hurrum blood. Effects of thbrinogen dedured by 'subtraction' . Circulat. Res. 13, 48, 1963.

11. Mohandas N., Bessis M.: Red cell deformability changes medsurcd by the ektacytometer . Blowd Cells 3, 199, 1974.

12. RAND W. P., Burton A. C.: Mechanical properies of red cell mombrane. 1. Membrane stitfiness and intracellulas prosure - Biophys. J. 4, $155,1961$.

13. Rero H. L., Barenes A. J., Lock P. J., Dormanty J. A., Dokmandy T. L.: A sirriple method for measuring crythrocyte deformability - J. din. Pathol. $29,855,1976$.

14. Siks J. A.: Automatic rccording of ratc of pasking of crychrocytes in blood by cerrtrifuge . Phys. Med. Biol. $15,9,1970$

15. Wells R. E. Jr, Cawhonski T, H. Cox F. J. Perera R. D.: Influcnce of librinogen on low properties of erythrocyte suspensions - Arrex. J. Physiol. 207, 1085, 1974.

Requests for reprinits should be addressed to:

Marco MOIA

Cantru pet l'Emofilin e la Trombori Arigelo Bianchi Bomomi

Istitusto di Clinica Medisa III Unizersitud degli Studi di Milano Osperdale Maggiore

Vú Pace 9, 201.22 Milurio - Italin 